\title{
Main directions of "Smart city" development in the republic of Kazakhstan
}

\author{
Urpash Shalbolova and Zita Kenzhegaliyeva* \\ L.N. Gumilyov Eurasian National University, 010008, 5, K. Munaitpasov str., Astana, Republic of \\ Kazakhstan
}

\begin{abstract}
The article focuses on paramount targets for developing "smart" cities in the Republic of Kazakhstan. The conducted studies substantiate the effectiveness of reforms in the housing and utilities sector of Kazakhstan in accordance with the branch state programs and the need for a comprehensive solution of the existing problems for the further successful development of smart cities. This study has been conducted in the framework of the project APO05134552 entitled "Economic evaluation of investment projects for the modernization of housing and communal services in the Republic of Kazakhstan".
\end{abstract}

\section{Introduction}

In modern society the construction of "smart" or "intelligent" buildings aimed at improvement the quality of the environment and saving building materials and energy increases the pace of urban development. The concept of "smart city" includes a large number of components starting from smart lighting up to smart stops.

Elements of "smart" building systems have long been known, but systems to provide comfortable conditions for residents and a quick response to changing needs with the help of embedded control devices have appeared recently. For the first time, the concept of "intelligent building" (intelligent building) originated in the United States in the early 1980s, evoking a wide public interest and spontaneous development [1]. According to Yu.A. Tabunshchikov, providing an optimal environment for a business and other work activities and reduction of operating costs are found to be the main criteria for the concept of an intelligent building [2]. An intelligent building is supposed to be equipped with means of automatic control over all life support systems.

Thus, the first "intellectual house", created by Professor of Computer Science Ken Sakamura, appeared in Tokyo in the late 1980s under the name of TRONE Intelligent House. It had special sensors that respond to air temperature and loud sounds. Subsequently, the invention of Bill Gates "intellectual building" also gained great fame and wide interest, because for the first time computer control was applied in the management of all engineering equipment, maintaining an optimal microclimate in each room of the building.

\footnotetext{
Corresponding author: urpash_sh@mail.ru
} 
Well-known expert in the field of smart technologies, Thomas Hartman, highlights the important technological aspects characteristic of a smart home:

- comfort and air quality;

- person-oriented ventilation, heating and air conditioning;

- individual microclimate control and feedback;

- automatic optimization of the system and verification of its effectiveness;

- connection with the IT infrastructure of the building [3].

As the expert noted, in addition to the integration of engineering systems into the local IT infrastructure, integration into the information network and the building system itself is necessary. This directly affects the control and effectiveness of the malfunction detection system.

As defined by the EEC and International Telecommunication Union, a smart sustainable city is an innovative city that uses ICT and other means to improve the quality of life, the efficiency of urban activities and services, and competitiveness while ensuring that they meet the needs of current and future generations taking into account economic, social, environmental and cultural aspects. [4]. A "smart" city is an agglomeration in which each resident is given access to all services in the form best suited to their needs. Creating smart cities means a process through which city centers become more inclusive, safe and resilient to climate change and able to more quickly respond to emerging development challenges. At the same time, "smart" cities are characterized by successful experience in attracting foreign direct investment and global sources, which have become socially and economically open to the rest of the world [5].

\section{Terms and Methods}

The research, conducted in the field of development of "smart" cities was based on theoretical methods of knowledge: analysis, induction and deduction. Comparative and dialectical-logical approaches were also been used in studying the international experience in the development of smart cities. The authors of the article have substantiated the relevance of the topic and identified the main trends and problems of "smart" cities development.

\section{Results}

According to experts, the growth of the urban population in the world by 2030 will reach 5 billion people, which means an increase in the need for "smart" cities. Thus, the annual growth of the urban population in the world, which has changed from $35 \%$ to $50 \%$ over the last decade, is alarming Kazakhstani city utilities services and obliges the involvement of efficient high technologies in their work.

In Kazakhstan the sphere of housing and communal services is still subsidized and operates through the implementation of State reforms in this area. During the years of independence, a number of reforms on the development of housing and communal services were implemented in the Republic of Kazakhstan: the Program "Affordable Housing 2020", the Program for the Modernization and Development of Housing and Communal Services to 2020, the State Program "Ak Bulak" for 2011-2020, the State Program for Infrastructure Development "Nurly Zhol" for 2015 - 2019 [6, 7, 8, 9]. The programs are implemented at the expense of the state budget, their effectiveness reflects the current state policy in the country, and, eventually, contributes to meeting the demand of the population and business entities. 
In the cities of the Republic of Kazakhstan, where more than $43 \%$ of the population lives, the development of housing and public utilities is provided in accordance with the state regional policy on the spatial development of the country and is aimed at forming monocities and agglomerations [10].

Thus, Kazakhstan, according to similar economic, natural, and socio-demographic characteristics are divided into four macro-regions - Northern, Central-Eastern, Southern, and Western, and hub cities of Astana and Almaty. Four agglomerations as Astana, Almaty, Shymkent and Aktyubinsk are created on their basis and priority economic specializations have been defined for each of them [11].

The implemented coordinated development of the infrastructure of the agglomerations in the country is expected to provide an integrated transport and information and communication systems, upgrading utilities with the use of new technological solutions. Therefore, to improve the efficiency of urban housing and communal services, the concept of "Smart City" is being implemented in the formed agglomerations [12].

The transition to Smart City involves the introduction of a whole range of modern technologies. In the power industry, these are intelligent energy systems capable of optimal distributing the load. In the sphere of housing services "smart home" technology is of high demand. In water supply system service it implies engineering network management technologies that can automatically find leaks, regulate rainwater runoff and divert flood waters.

As part of the implementation of Smart City in the field of housing and communal services, it is proposed to focus on achieving the following goals:

- improving the quality of public services;

- improving the state of the urban environment for comfortable living of the population;

- preventing accidents on engineering networks by organizations serving housing stocks.

Table 1 presents the initiatives envisaged by the Smart City system and their characteristics and purpose.

Table 1. Smart City Initiatives

\begin{tabular}{|c|c|c|}
\hline & Item & Characteristic \\
\hline 1 & $\begin{array}{l}\text { Automatic } \\
\text { transfer of meter } \\
\text { readings }\end{array}$ & $\begin{array}{l}\text { Designed to take readings for utilities in order to make commercial } \\
\text { calculations with the supplier and consumers. }\end{array}$ \\
\hline 2. & Smart lighting & $\begin{array}{l}\text { e modern concept, which involves the use of specialized street lamps } \\
\text { ntrolled by intelligent platforms }\end{array}$ \\
\hline 3. & $\begin{array}{l}\text { Automated } \\
\text { process control } \\
\text { system }\end{array}$ & $\begin{array}{l}\text { Multi-level information-measuring centralized system designed to } \\
\text { monitor and control technological processes and equipment at industrial } \\
\text { facilities. }\end{array}$ \\
\hline 4. & $\begin{array}{l}\text { Meteorological } \\
\text { sensor system }\end{array}$ & $\begin{array}{l}\text { Monitoring and forecasting of hydrometeorological variables using } \\
\text { mesoscale modeling, as well as calculating the distribution of stormwater } \\
\text { in different sewage basins. }\end{array}$ \\
\hline 5. & E-co & $\begin{array}{l}\text { Unified information resource in the sphere of housing and communal } \\
\text { services, consisting of an open part, where information is publicly } \\
\text { available, and a closed part, where personal offices of citizens, } \\
\text { authorities and participants of the housing and utilities market are used. }\end{array}$ \\
\hline 6. & $\begin{array}{l}\text { Intellectual water } \\
\text { network }\end{array}$ & $\begin{array}{l}\text { Integrated set of products, solutions and systems that allow utilities to } \\
\text { remotely and continuously monitor and diagnose problems, prioritize } \\
\text { and manage maintenance problems, and use data to optimize all aspects } \\
\text { of the water distribution network. }\end{array}$ \\
\hline 7. & $\begin{array}{l}\text { Intellectual } \\
\text { power supply } \\
\text { system }\end{array}$ & $\begin{array}{l}\text { Modernization of power supply networks, using information and } \\
\text { communication networks and technologies to collect information about } \\
\text { energy production and energy consumption, which automatically }\end{array}$ \\
\hline
\end{tabular}




\begin{tabular}{|c|l|l|}
\hline & & $\begin{array}{l}\text { improves efficiency, reliability, economic benefits, as well as } \\
\text { sustainability of production and distribution of electricity. }\end{array}$ \\
\hline 8. & $\begin{array}{l}\text { Tidal drainage } \\
\text { system }\end{array}$ & $\begin{array}{l}\text { Provides a phased, manageable approach to collecting information on } \\
\text { cleaning and drainage sewage. }\end{array}$ \\
\hline 9. & Climate control & $\begin{array}{l}\text { The climate control system ensures the rational use of thermal energy } \\
\text { and the creation of comfortable living and working conditions }\end{array}$ \\
\hline 10. & $\begin{array}{l}\text { Home } \\
\text { management } \\
\text { platform }\end{array}$ & $\begin{array}{l}\text { Intended for renting common property sites in condominium for } \\
\text { financial benefits for apartment owners }\end{array}$ \\
\hline 11. & Snow load sensor & Ensures safe snow removal time from house roofs \\
\hline 12. & $\begin{array}{l}\text { Fire protection } \\
\text { system }\end{array}$ & $\begin{array}{l}\text { Is capable of independently recognizing a fire, warning of its occurrence, } \\
\text { starting the extinguishing process and helping people in the evacuation } \\
\text { process. }\end{array}$ \\
\hline 13. & $\begin{array}{l}\text { Smart security } \\
\text { system }\end{array}$ & $\begin{array}{l}\text { Automated complex for the protection of various objects of property } \\
\text { from processes or phenomena of a criminal nature. }\end{array}$ \\
\hline 14. & Smart lift & $\begin{array}{l}\text { Innovative development remembers data on passenger traffic during the } \\
\text { day, keeps under control and analyzes the state of the lift by logical and } \\
\text { high-quality electronic judgment. }\end{array}$ \\
\hline 15. & Smart yard & $\begin{array}{l}\text { Designed to stimulate modern children leading a sedentary lifestyle to } \\
\text { spend more time on the street and play with their peers in a variety of } \\
\text { mobile and healthy games. }\end{array}$ \\
\hline
\end{tabular}

In general, the Smart City system, in which the existing resources of urban services are used in the best possible way, ensures maximum safety of urban life. The Smart City system combines such components as an intelligent transport system (ITS), geo-information (GIS), e-police, e-education and e-health.

Kazakhstan has successfully implemented the Smart Astana brand, created within the framework of the "roadmap" of the "Astana - smart city" project with the key goal to assist the authorities in introducing innovations that could bring related results throughout the country and promote economic diversification. "Roadmap" of the Smart Astana concept implies the optimization of 6 characteristics combination that make up "smart city": "smart" economy, "smart" management, "smart" life, "smart" mobility, "smart" people and "smart" «environment. The application of all parts of a "smart" city is intended to result in an improvement in the quality of life, improvement of housing and communal services, renovation of utility networks and increasing safety in cities.

In order to further introduce a unified intellectual information system in the housing and utilities sector in 16 regions of Kazakhstan, more than 15,000 apartments are involved in the pilot project for installing home-based heat, water and electricity meters. It is supposed to equip neighborhoods with "smart" traffic lights, stops, parking and lighting, the introduction of "smart" transport, video surveillance in the courtyards and on the streets, as well as other innovations.

It is also planned to connect "smart" residential areas to a single intellectual information system under the working title E-SHANYRAQ. Also, 51 natural monopolies and 28 condominiums will be connected to the unified system. The implementation of such a project in pilot houses will allow all users of the system to assess its capabilities and ensure its effectiveness.

The lack of accurate data on the number and condition of housing stock, equipping them with metering devices and decentralized procurement of instruments operating at different standards induced to start inventory of condominiums. As for the digitization of housing and public utilities in general, it should be noted that in Kazakhstan there is no single approach to information resources in the industry. Currently, the Ministry of Investment and Development of the Republic of Kazakhstan is considering amendments to the Law of the Republic of Kazakhstan "On Housing Relations", which will include a provision on the 
creation of a unified information system of the infrastructure and housing complex, as well as the necessary requirements and standards.

The planned digitalization of housing and communal services in Kazakhstan will ensure transparency and make the entire infrastructure of the housing and utilities infrastructure "smart". The digitalization of utility networks enables the automatic collection of readings from metering devices, that to eliminate the human factor and ensure transparency in billing. The online home management system will ensure transparent management of the operating activities of management companies. In addition, the planned digitization of natural monopolies will ensure the transparency of their activities and improve the balance of energy production and consumption.

\section{Conclusions}

For the further successful development of "smart" cities in Kazakhstan in short and medium term, it is necessary to solve the following problems:

1. Improving the coordination of efforts at the national and municipal levels of innovation policy.

2. Increasing transparency of the legal framework and the protection of privacy.

3. Involving citizens in implementation of projects

4. Engaging in national and international knowledge sharing networks.

5. "Smart" adjustment in the construction of new infrastructure by attracting private and public entities.

\section{References}

1. Zhilenkov N. "Smart home - development prospects", STA, 60-63 (2005)

2. Yu.A. Tabunshikov, M.M. Brodach, N.V. Shilkin, ABOK, 181 (2003)

3. Nizhny Novgorod Business Journal, 30, 21-22 (2008)

4. United Nations Ecinomic Commission for Europe, "United for Smart Sustaineble Cities (U4SSC)" http://www.unice.org/housing-and-land-management (2018)

5. United Kingdom, Department for Business, Innovation and Skills, Smart Cities: Background Paper (Access Mode: http://www.gov.uk/government/uploads/, London, (2013)

6. The Program “Affordable Housing 2020", approved by the Government of the Republic of Kazakhstan No. 821. [Digital resource: http://online.zakon.kz] (2012)

7. The Program for the Modernization of Housing and Communal Services of the Republic of Kazakhstan for 2011-2020, approved by the Decree of the Government of the Republic of Kazakhstan 473. [Digital resource: http://online.zakon.kz] (2011)

8. The Program "Ak bulak" for 2011 - 2020, approved by the Decree of the President of the Republic of Kazakhstan No. 570. [Digital resource: http://online.zakon.kz] (2012)

9. The State Program for Infrastructural Development "Nurly Zhol" for 2015-2019, approved by the Decree of the President of the Republic of Kazakhstan No. 10301030. [Digital resource: http://online.zakon.kz] (2015)

10. Official statistical information (by branches)- http://www.stat.gov.kz

11. The program for Regional Development to 2020, approved by the Government of the Republic of Kazakhstan No. 728 [Digital resource: http://online.zakon.kz] (2014)

12. The program "Digital Kazakhstan", approved by the Government of the Republic of Kazakhstan No. 827. [Digital resource: http://www.primeminister.kz)], (2017) 